Perspectives in Affective Disorders 


\section{Advances in Biological Psychiatry}

Vol. 21

Series Editors

D. Ebert Freiburg

K.P. Ebmeier Edinburgh

W.P. Kaschka Ulm

T. Rechlin Rendsburg

KARGER 
International Symposium ' 25 Years Weissenau Depression Unit', Weissenau, Germany, September 14-15, 2001

\section{Perspectives in Affective Disorders}

Volume Editor

W.P. Kaschka Ulm

13 figures and 32 tables, 2002 


\section{Wolfgang P. Kaschka}

Department of Psychiatry I

University of Ulm

Postfach 2044

D-88190 Ravensburg (Germany)

\section{Library of Congress Cataloging-in-Publication Data}

International Symposium "25 Years Weissenau Depression Unit” (2001: Weissenau, Germany)

Perspectives in affective disorders / International Symposium "25 Years Weissenau

Depression Unit," Weissenau, Germany, September 14-15, 2001; volume editor, W.P. Kaschka.

p. ; cm. - (Advances in biological psychiatry, ISSN $0378-7354$; v. 21)

Includes bibliographical references and indexes.

ISBN 3805574398 (alk. paper)

1. Affective disorders-Congresses. 2. Depression, Mental-Congresses. 3. Biological

psychiatry-Congresses. I. Kaschka, Wolfgang P. II. Title. III. Series.

[DNLM: 1. Mood Disorders-therapy-Congresses. 2. Biological Psychiatry-methods-Congresses. 3.

Psychotherapy-methods-Congresses. 4. Psychotropic Drugs-therapeutic use-Congresses. WM 171

I616p 2002]

RC537.I574 2001

$616.8^{\prime} 527-\mathrm{dc} 21$

Drug Dosage. The authors and the publisher have exerted every effort to ensure that drug selection and dosage set forth in this text are in accord with current recommendations and practice at the time of publication. However, in view of ongoing research, changes in government regulations, and the constant flow of information relating to drug therapy and drug reactions, the reader is urged to check the package insert for each drug for any change in indications and dosage and for added warnings and precautions. This is particularly important when the recommended agent is a new and/or infrequently employed drug.

All rights reserved. No part of this publication may be translated into other languages, reproduced or utilized in any form or by any means electronic or mechanical, including photocopying, recording, microcopying, or by any information storage and retrieval system, without permission in writing from the publisher.

(C) Copyright 2002 by S. Karger AG, P.O. Box, CH-4009 Basel (Switzerland)

www.karger.com

Printed in Switzerland on acid-free paper by Reinhardt Druck, Basel

ISSN 0378-7354

ISBN 3-8055-7439-8 


\section{Contents}

VII Preface

Psychiatric Care with Regard to Depressed Patients

1 Historical Comments on the Foundation of the Weissenau Depression Unit

Hole, G. (Ravensburg)

8 Inpatient Treatment of Depression:The Significance of Special Units for Patients with Depressive Diseases. Survey, Conception and Current State of Experience

Wolfersdorf, M. (Bayreuth)

25 Screening and Utilization of Treatment in Mothers with Postnatal Depression

von Ballestrem, C.-L.; Strauss, M. (Stuttgart); Kächele, H. (Stuttgart/Ulm)

Basic Research in Affective Disorders

35 Genetics of Mood Disorders: Current Status of Knowledge and Prospects

Maier, W. (Bonn)

63 Functional Neuroimaging of Depression

Erk, S.; Walter, H.; Spitzer, M. (Ulm)

70 Affective Disorders and Alterations of Cardiac Autonomic Nervous System Control

Rechlin, T. (Rendsburg) 
Therapeutic Perspectives in Affective Disorders

79 New Antidepressants in Comparison with Classical Tricyclics. Mechanisms of Action and Clinical Evaluation

Broocks, A.; Junghanns, K. (Lübeck); Thiel, A. (Rotenburg/Wümme);

Gleiter, C.H. (Tübingen); Bandelow, B. (Göttingen)

95 Therapy with Antidepressants: Pharmacogenetic Aspects

Baumann, P.; Zullino, D.F. (Prilly-Lausanne); Jaquenoud Sirot, E. (Brugg);

Paus, E.; Eap, C.B. (Prilly-Lausanne)

112 Molecular Mechanisms of Action of Mood Stabilizers in Bipolar Disorder van Calker, D. (Freiburg)

137 Antisuicidal Effect of Lithium as a Criterion for the Selection of Appropriate Long-Term Medication in Bipolar Patients

Berghöfer, A. (Berlin); Bauer, M. (Berlin/Los Angeles, Calif.);

Müller-Oerlinghausen, B. (Berlin/Köln)

146 Mechanisms and Management of Weight Gain Associated with

Drug Treatment of Affective Disorders

Zimmermann, U.; Kraus, T.; Pollmächer, T. (Munich)

167 Electromagnetic Stimulation and Affective Disorders

Ebmeier, K.P.; Lappin, J.M. (Edinburgh)

178 Cyclothymic But Not Depressive Temperament Influences the Mood of Another Person in Social Interactions

Hautzinger, M.; Meyer, T.D.; Pheasant, B.L. (Tübingen)

188 Pathological Crying: Modern Treatment Options

Kaschka, W.P.; Meyer, A.; Schier, K.R.; Fröscher, W. (Ulm/Ravensburg)

\section{Author Index}

198 Subject Index 


\section{Preface}

In 2001, we celebrated the 25th anniversary of the Depression Unit at the Weissenau Centre for Psychiatry, First Department of Psychiatry, University of Ulm. This was founded as the first special unit in Germany for the treatment of affective disorders and was the start of a development which has now led to there being well over 30 depression units in the German-speaking area and which has resulted in a great improvement in the care of patients with affective disorders.

The anniversary was taken as the occasion for organizing an international scientific symposium on September 14-15, 2001, at the Weissenau Centre for Psychiatry, in collaboration with the University of Ulm and the working party of the depression units. The aims of the symposium included a survey of past work and a summary of the present position and future prospects in basic research, diagnosis, therapy and the care of affective disorders.

In 14 plenary lectures and 6 working groups, decisive new developments were presented which have been milestones in basic research or in the diagnosis, pharmacotherapy and psychotherapy of affective disorders. These include improvements in quantitative brain morphology and developments in genetics, neurochemistry, neuropharmacology, pharmacogenetics, electrophysiology, structural and functional imaging and, particularly, psychotherapy.

Without claiming to be complete, the present volume is intended to make this information available in concentrated form to clinical psychiatrists and psychotherapists, to students and to all other professional groups who participate in the treatment of patients with affective diseases. I would like to express my thanks to all who have helped to translate this project into reality.

Wolfgang P. Kaschka 